\title{
Analysis of the marine shrimp culture production chain in Southern Brazil
}

\author{
RODRIGO R. FREITAS ${ }^{1}$, LUIS VINATEA ${ }^{2}$ and SÉRGIO A. NETTO ${ }^{3}$ \\ ${ }^{1}$ Universidade Federal do Rio Grande, Departamento de Oceanografia, Programa de Pós-Graduação em Aqüicultura \\ Laboratório de Maricultura, Estação Marinha de Aquacultura, Cassino, Caixa Postal 474, 96201-900 Rio Grande, RS, Brasil \\ ${ }^{2}$ Universidade Federal de Santa Catarina (UFSC), Centro de Ciências Agrárias, Departamento de Aqüicultura \\ Rua Beco dos Coroas, Barra da Lagoa, Caixa Postal 10136, 88063-600 Florianópolis, SC, Brasil \\ ${ }^{3}$ Laboratório de Ciências Marinhas (LCM), Universidade do Sul de Santa Catarina (UNISUL) \\ Av. Colombo Sales, 84, Centro, 88790-000 Laguna, SC, Brasil \\ Manuscript received on March 5, 2008; accepted for publication on March 4, 2009; \\ presented by ELIBIO L. RECH
}

\begin{abstract}
This study was elaborated to identify and describe the main links of the sea shrimp productive chain in the municipal district of Laguna, historically known as the main sea shrimp (Litopenaeus vannamei) production area in the State of Santa Catarina, Brazil. The study, held from April to July 2005, previously identified the local productive process through observation, interviews and bibliographical research. Afterwards, specific questionnaires were elaborated for each of the several segments connected to the local activity. A total of 90 interviews were conducted, intending to map out the procedures and functionality of the productive chain, from the necessary inputs for production to the moment of shrimp acquisition by final consumers. Results indicated that the entire productive chain requires actions that range from improvement of sanitary and genetic conditions of larvae to product commercialization. Reduction of bureaucracy in public organs, better investment credit conditions, improvement in productive practices, training of technical and productive labor, and reduction of production costs will not occur until industrialization politics and commercialization of local production are standardized.
\end{abstract}

Key words: Litopenaeus vannamei, marine shrimp culture, production risks, supply chain.

\section{INTRODUCTION}

In Southern Brazil, commercial cultivation of sea shrimp initiated during the seventies, in the state of Santa Catarina (SC) (Fig. 1). However, it was only in the eighties that it acquired actual business characteristics (Barbieri Júnior and Ostrensky Neto 2002, Costa et al. 1998). Exponential growth of the activity was confirmed through censuses performed by the $\mathrm{ABCC}$ (Associação Brasileira de Criadores de Camarão) in 2003, when it was noted that, between 1997 and 2003, pond areas increased in more than $400 \%$, and by the ICepa/SC (Centro de Estudos de Safras e Mercados 2004), which reported a leap

Correspondence to: Rodrigo Randow de Freitas

E-mail: rodrigorandow@ig.com.br from 35 ha of occupied pond areas in 1998 to 1361 ha in 2004.

In the state of Santa Catarina, with the introduction of species Litopenaeus vannamei around 1998 and the creation of the Programa Estadual de Cultivo de Camarões Marinhos (May 22, 1999), the activity became promising (Costa et al. 1998). At the time of its establishment, there was an expectation that 3000 jobs would be created in the state, with a $\mathrm{R} \$ 50$ million/year revenue. The project initiated with the creation and preparation of areas destined for cultivation. The state's production reached approximately 50 tons in 1998, and in 2004 production reached 4267 tons/year (Costa et al. 1998).

The municipal district of Laguna has historically constituted the main sea shrimp production/growth area 
in the state of Santa Catarina. Farms settled down along the entire lagoon compound, with approximately 83 farms occupying 1536 ha of water in roughly 453 pond farms at the present (Costa et al. 1998).

With the objective of providing a better product for the customer, as well as improving productive efficiency, studies on productive chains aim towards raising efficiency and production when facing difficulties imposed by increasingly globalized and competitive commercial transactions. This study is intended for identifying and describing the current links of the shrimp culture productive chain in the municipal district area of Laguna, SC, in order to generate information that contributes towards overcoming impediments and permitting the maximization of existent potentialities that are not yet being explored.

\section{MATERIALS AND METHODS}

\section{Site Selection}

This study was developed in the estuarine system of Laguna, Southern Brazil $\left(28^{\circ} 12^{\prime}\right.$ to $28^{\circ} 30^{\prime} \mathrm{S} ; 48^{\circ} 38^{\prime}$ to $48^{\circ} 55^{\prime} \mathrm{W}$ ), with a total area of approximately $183.94 \mathrm{~km}^{2}$. Three main lagoons form the system: Santo Antonio, at the Southern portion $\left(33.85 \mathrm{~km}^{2}\right)$, Imaruí $\left(86.32 \mathrm{~km}^{2}\right)$, at the central area, and Mirim, at the North $\left(63.77 \mathrm{~km}^{2}\right)$ (Fig. 1).

\section{Methods}

Based on a previous identification of the regional productive process, through observation, interviews and bibliographical research, specific questionnaires were elaborated for each sector related to the local shrimp culture. In this manner, it was possible to accompany the sectors and functionality of the productive chain, starting from the necessary inputs for production up to the moment of shrimp acquisition by the final consumer.

Data was collected from April to July 2005, with interviews of three laboratories, three feed manufacturer representatives, three aerator factory representatives, 30 producers, one creator association, two producer cooperatives, four technicians, one technical support and extension company, two research and teaching institutions, two control and inspection agents, one Institution of Fomentation and Incentive to Credit, one processing plant, three middlemen, three fish markets, two

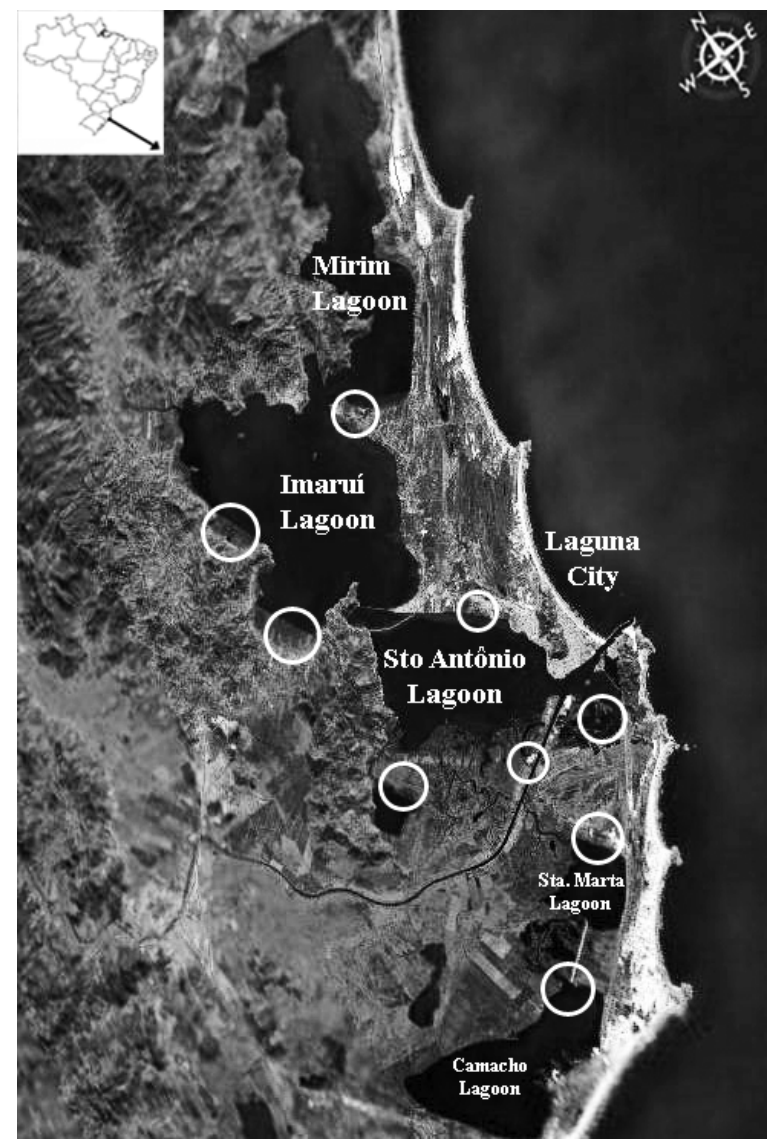

Fig. 1 - Study area. Circles represent researched farms.

supermarkets, three restaurants, one hotel and 25 final consumers. In this manner, interviews included all links of the sea shrimp productive chain at the area (Fig. 2), with a total of 90 interviewees.

\section{RESULTS AND DISCUSSION}

The Input group (Fig. 2) considered that shrimp feed presents high cost, and that it is difficult to understand the reasons for constant increases in prices. Feed quality was evaluated as good, as was delivery time and aftersales service by the producers. The companies were very motivated in participating in the growth of the activity, and do not perceive any difficulties in supplying the regional demand for shrimp feed, as previously established by Ormond et al. (2004). Aerators also received a positive evaluation in terms of durability, technical support, replacement pieces and maintenance. Other inputs, such as fertilizers, also received good evaluations regarding prices and easiness of acquisition. 


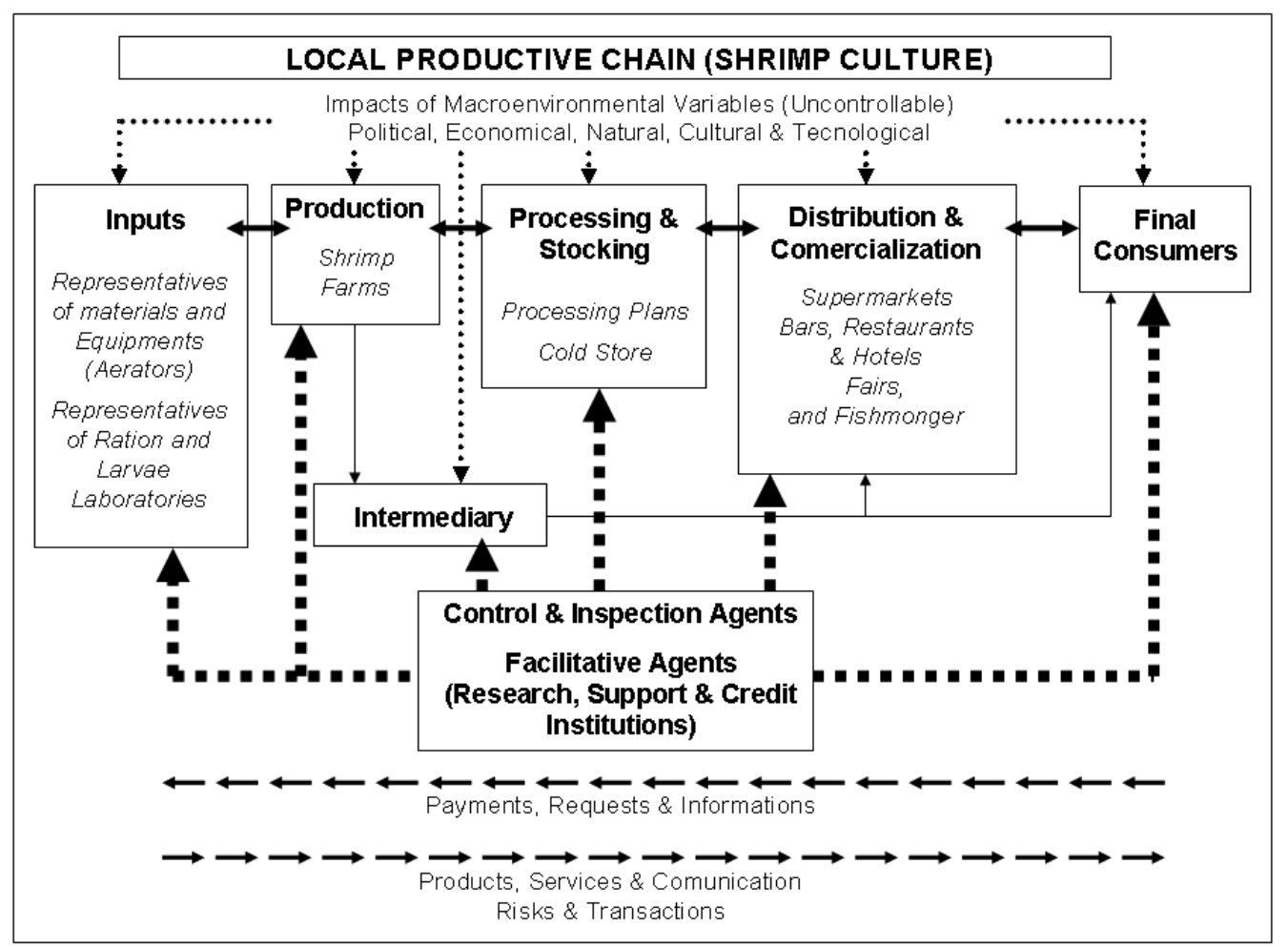

Fig. 2 - Local shrimp culture productive chain.

Most interviewees reported motivation in working with the local shrimp culture, regardless of problems such as the white spot virus (WSSV), which causes break in production and halts facilities. Even while undergoing several difficulties, every party involved in this process is optimistic for the future due to decrease in production costs and improvement of farm production efficiency (Table I).

Due to the continuous search for productivity and profitability, producers find themselves in high bank debt, causing production loss. Other reasons for their debt are bad loan management and occurrence of WSSV at the area. Shrimp culture is a high-risk activity; therefore, producers must always be aware of current market transformations, local climate and diseases. Large debts and risks have imposed a new attitude among administrators, which is to enlarge profits and avoid deficits in order to stay in business (Razzolini 2001, Guimarães and Brisola 2001, Christopher and Towill 2002).

The producers point out super-harvests of native shrimp from the municipal district of Rio Grande, RS, as the main factor of economical losses because of price fall with shrimp commercialization. But in an extremely competitive globalized world, it is not advisable that producers become unfamiliar with the production risks. They must be prepared for any possibility, such as drops in the product's commercial value (Béné et al. 2000). Knowing their own company and the possible opportunities and threats of the market are necessary for the establishment of future goals.

The lack of appropriate loans needed for production also increases production costs, reducing final profitability of the commodity. This is especially true when considering that the producer many times tends to harvest the shrimp before the commercially appropriate moment for payment of contracted debts. An appropriate loan provides autonomy to the small producer, so that they can better manage the production and commercialization of their product, resulting in larger profits (Ormond et al. 2004).

On the other hand, if producers do not have money to invest on their property, a portion of the producers have no choice but to take on more loans, being drawn into a vicious circle of loan acquisitions. Bank credit destined to finance production and investment in efficient 


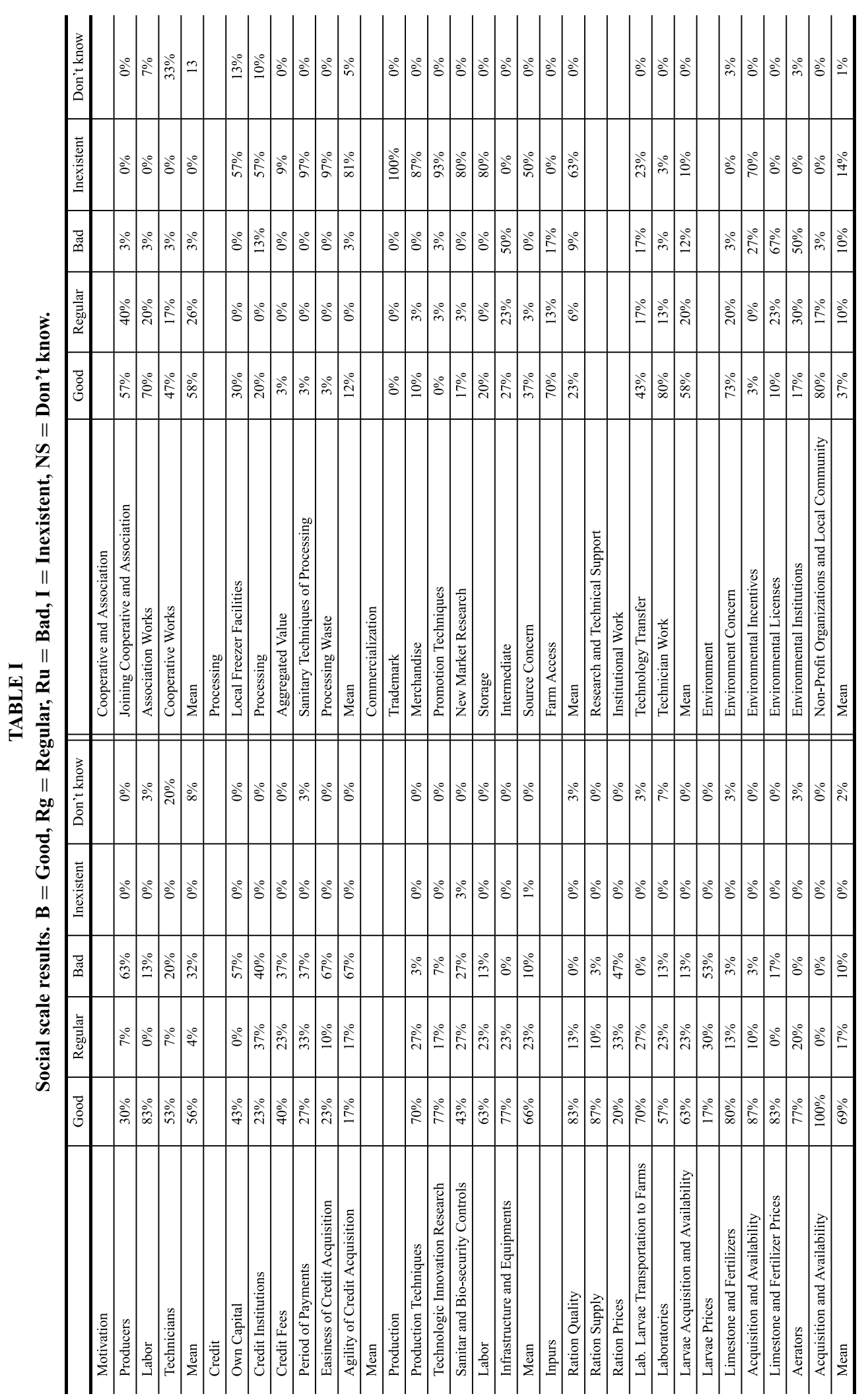


TABLE II

Possible obstacles in the local productive chain.

\begin{tabular}{l|l|l}
\hline \multicolumn{1}{c|}{ Laboratories } & \multicolumn{1}{c}{ Ration } & Aerators \\
\hline White Spot Virus - WSSV & White Spot Virus - WSSV & White Spot Virus - WSSV \\
\hline Shut-down Facilities - WSSV & Noncompliance & Noncompliance \\
\hline Scarce Credit Lines & Scarce Credit Lines & Bad Practices of commissions by Scale \\
\hline Lack of representatives from ACCC & Long Payments Plans & Low technologic innovation Research \\
\hline High Production Costs (Ration, Energy and Employers) & High Production Costs & Low Business Professionalism-Producers \\
\hline Poor Acclimatization & Scarce Raw Material & Bad Farm Access \\
\hline Low Genetic Improvement of Shrimp & Shrimp Super Offer from Rio Grande - RS & Bad Farm Access \\
\hline Inappropriate Transport of the Larvae to the Farms & Bad Farm Access & Low Commercialization Prices \\
\hline Poor Bio-security Practices & Low Commercialization Prices & \\
\hline Bad Farm Access & & \\
\hline Low Commercialization Prices & & \\
\hline Unproductive Farms - WSSV & & \\
\hline $\begin{array}{l}\text { Discontinued Work by Support and Research Institutions } \\
\text { Estate Building - UFSC }\end{array}$ & & \\
\hline $\begin{array}{l}\text { Producers Uninformed or with Bad Intentions } \\
\text { Not Following Environmental Rules }\end{array}$ & & \\
\hline
\end{tabular}

productive techniques for properties are badly managed. Also, they are often inadequately expended, such as in payments of previous debts or even acquisition of personal goods. In that manner, at the first sign of production failure, the producers cannot pay their acquired loans.

Producers are aware of the existence of contract breaks, payment difficulties, bureaucracy and few credit lines destined to the activity. Producers classify interest rates and financings from good to regular, therefore demystifying the notion that the credit problem is only in relation to bank institutions, which are forced to ask for more warranties in order to provide loans. It is essential for the producer not to become excessively dependent of such bank loans.

In terms of accessing road conditions, it was evident through the interviewees that a larger attention by public institutions is necessary. Unpaved and precarious access roads are a big obstacle for acquisition of ration and larvae as well as commercialization of the final product, and also hold back the economic development of the community that utilizes those accesses. It was also verified that, when arriving at the farm, larvae are not acclimated as is required by a qualified professional. These impediments need to be reviewed and solved in the imminent future (Table II).

The accelerated growth of the activity at the area also created countless conflicts on how to use common resources. This generated a negative image of the activ- ity on the community, public service and environmental organs. In this manner, meetings for the promotion of understandings and agreements are necessary. This will also put an end to the belief that environmental licenses serve only as a money source to the local environmental organs, requested only as a necessity for initiating activities.

The level of environmental conscience and concern of the producers with the environment surrounding their properties is directly linked to their own survival in the activity. Producers request more support and inspection of the daily routine at the farms, as well as education and control from the environmental organs. Better organization of the actions and rules that orientate the activity is necessary in order to avoid generating misunderstandings that harm the activity and its productive chain.

In order to improve and encourage the established productive practices, environmental organs are strongly attempting to mitigate the current environmental impacts of farm construction and operation, such as disposal of cultivation effluents into the ecosystem and impacts of the conversion of terrestrial into aquatic ecosystems, with actions such as effluent treatment (Vinatea 1999).

There is no easy way to measure the control of environmental impacts and inadequate use of natural resources; in order to accomplish that, it is necessary to establish economic incentives and harden the laws (Cordero et al. 2005). It is essential that the obligations and 
regulations made to the producers be regarded as necessary for the sustainability of the activity, and in the future become spontaneous attitudes for seeking the rational use of the local common resources. It is important to see that the fast commercial and productive worldwide growth of aquaculture is usually accompanied by environmental degradation and distancing of social responsibilities (Brummett and Williams 2000).

The ACCC (Associação Catarinense de Criadores de Camarão) complicated the regional political-economical scenery, fact evidenced by the lack of cooperation among its own members. Producers act independently without normative and surveillance by the entity. Actions for the benefit of all, intended to improve efficiency and reduce production costs, are not put into practice because individual needs surpass collective needs. This practice goes completely against the competitive world pattern of agribusiness, which debates the importance of integrating all links of any productive chain. By creating common practices, the producers generate knowledge and aggregate value to their product (Lazzarini et al. 1995).

Due to the fragile politics and economy of the local productive chain, it is fundamental that the ACCC works as an "Agency of Local Competitiveness", destined to generate programs with the objective of developing the competitive capacity of the activity. In that manner, it could create a channel of dialogue, integrating the entity and the productive chain with decisionmakers, establishing goals and incentive actions for the growth of the activity. These actions will help to generate jobs, income and technological and regional development (Pio and Maldonado 2005). This would also open up the possibility of a harmonic channel of relationships capable of gathering the town, state and nation, aiding in the solution of the activity's problems by providing appropriate infrastructure (road access) and research (Brummett and Williams 2000).

As for quality of labor used in the farms, it received good and bad evaluations from the interviewees. Major obstacles include the need for constant training and the lack of recognition, by some producers, that employees are essential for the activity, considering that they are responsible for caring of the shrimp, which in turn generates profits. Also, farm workers receive low wages and possess low education, therefore needing to complement their income with other activities, as described in Schaefer and Panitz (A.L.C. Schaefer and C. Panitz, unpublished data). This was a negative fact established by this research.

In terms of technicians, it was evidenced that they are not motivated. Due to the fact that they do not have autonomy to make changes, they are considered by some producers useless and unnecessary in accomplishing farm handling, being the first to be cut of the payroll at the first sign of problems. They also receive low wages and do not have labor contracts.

The producers are also facing many restrictions at the time of commercialization, depending entirely on the intermediate persons. By selling their products to few buyers, the producers must accept prices determined by the mediators. Therefore, the generated profit does not provide satisfactory return to the producers, who face alone the production risks.

The Shrimp Producers of Laguna Cooperative (Copercamarão) needs to fill the gap among producers and consumers. Since the Cooperative is in its initial stages, their actions are still restricted to stockpiling and freezing, but nevertheless it is a promising idea. The Cooperative has the double-function of gathering people and improving business, and users of the Cooperative also need to incorporate the double-function of being owners and users of the enterprise (Antonialli 1998). Due to that fact, group trust and motivation are a major part of the success of the enterprise. A good example is the relationship of the Cooperative of Aquacultures from the Espírito Santo State, which sells their products directly to supermarkets (Piedade et al. 2002).

Storage techniques after harvest also need to be improved. Sanitary problems are common. Dirty boxes and inadequate trucks occasionally bring problems at the moment commercialization due to reduced product quality and consequent price reduction. Adequate storage and handling practices are crucial factors for product quality, preserving maximum sensorial and nutritional qualities for consumption (Neiva 2002).

Traditional markets treat all their customers equally; therefore, they must know how to interact with potential consumers in an individualized way in order to discover their desires and needs. Every process be- 
gins and ends with the consumer, so it is necessary to identify market opportunities through the needs of the final customer (Razzolini 2001, Naim et al. 2002). Understanding the local productive chain is important due to the fact that it is a sensitive system. The product (shrimp) reaches the consumer and the information on consumption returns to producers, which in turn can adopt fast measures to solve possible distortions in the system (Quinn 1997, Christopher and Towill 2002). Consumers should be more conscious about what they are consuming. Such concern of consumers with product does not exist, fact confirmed by the answers of the interviews on the productive chain.

Value aggregation, creation of trademarks and advertising of the product do not exist at the area and should become priorities for the local shrimp culture. Trademarks, for instance, identify products, simplify choices and reduce risks for the consumers. All producer interviewees said that their produced shrimp are only sold fresh, without any aggregated value. This limits their final price and does not support the growing demand for different products and the implementation of various health procedures required by several importer countries. For instance, shrimp classified as headless, wrapped and frozen would be sellable in only about $40 \%$ of the North American market (Ormond et al. 2004). Such setback pointing in the local productive chain is also beginning to be solved by the Copercamarão initiative.

Cultural, economical, social, familiar and psychological aspects interfere in the consumer's behavior, affecting the buying decision. It can be said that the purchase process of a certain product is divided into five stages: recognition of necessity, research for relevant information, evaluation of alternatives, purchase decision and after-sale evaluation (Guimarães and Brisola 2001). Therefore, through this research, we have discovered that the major decision factors for purchasing this product at the area are price, followed by quality (Fig. 3). Price is still considered the largest difficulty in the diffusion of a shrimp alimentary habit among the Brazilian people (Ormond et al. 2004).

The main concern for the consumer is to receive a product with the best possible quality, speed and with a low and competitive price. In order for that to be pos-

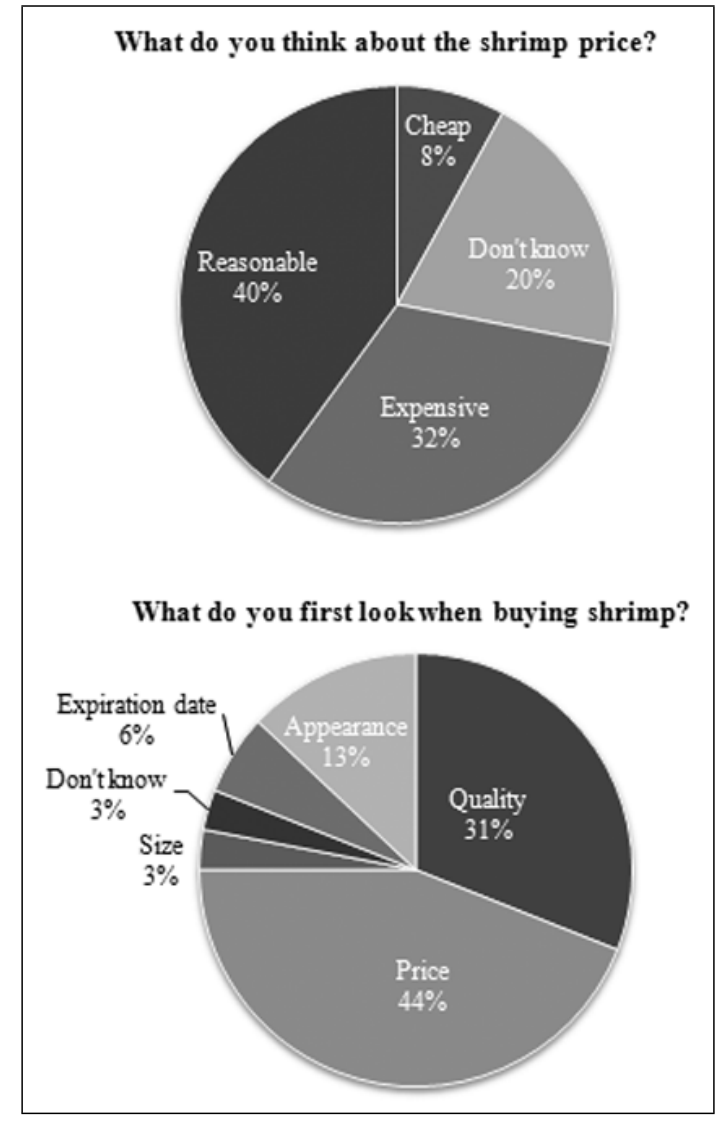

Fig. 3 - Questions destined for final consumers.

sible, further studies for discovering the local demand for captive shrimp are necessary. Considering that the demands are difficult to predict, increases in the local population income are an important aspect that will affect the demand for these products (Brummett and Williams 2000, Christopher and Towill 2002). Consumers will be benefited not only by low prices, but also by a constant offer of the product in commercial establishments (Ridler and Kabir 1989).

The interviewed consumers do not consider the consumption of captive shrimp unnecessary, different from what is observed in the USA, where shrimp products are considered a luxury, reserved for special occasions and expensive restaurants (Barbieri Júnior and Ostrensky Neto 2002). It was verified that more researches on the local population alimentary habit would be necessary in order to reveal expectations and elaborate ways of increasing consumption, due to the fact that the Brazilian national market for shrimp is concentrated in Rio de Janeiro and São Paulo states. 
The commercial and consuming establishments also reported that the native species of the area (Farfantepenaeus paulensis) is better accepted by the consumers than the captive shrimp. This problem was also evidenced by Béné and collaborators (2000) in their study of Penaeus subtilis shrimp market dynamics at the French Guiana area. The fact that the local community dislikes the cultivated shrimp because of its flavor after cooked has to be reviewed. Also, the productive chain needs to distribute their product to local markets. Today, quality is the big distinction between products (Neiva 2002).

The local community prefers native shrimp; consumption of captive shrimp in the summertime can be explained by the larger concentration of tourists at the area. There is need to perform specific marketing research in order to reach those potential consumers in that determined season.

Shrimp waste from processing should also be better employed and could benefit countless groups of the local productive chain. For example, ecdise could be used by local families for extraction of chitin, which could in turn be used in glue production for orthodontic material and the aeronautical industry. Heads could also be used for the production of meals for the feed industry.

Making these changes will have major effects of extreme social importance on the community, generating income and sustenance for many families excluded from economical life by utilizing products that would otherwise be discharged in the local ecosystem, generating pollution.

\section{CONCLUSIONS}

As a result of this study, it was observed that the local productive chain groups are waiting for a management capable of consolidating, establishing and enlarging the niches that have not yet been explored. Projects that will make production dynamic and the chain more effective should be treated as priority, if there is real desire to strengthen this activity in the future.

\section{RESUMO}

O presente estudo foi elaborado para identificar e descrever os principais elos da cadeia produtiva no município de Laguna, região que historicamente constitui-se em principal área de produção de camarão marinho (Litopenaeus vannamei) em Santa Catarina, Brasil. O estudo foi desenvolvido de abril a julho de 2005, a partir de uma prévia identificação do processo produtivo local, através de observação, entrevistas e busca bibliográfica. Foram elaborados questionários específicos para os vários segmentos atrelados à atividade local. Foi realizado um total de 90 entrevistas, pretendendo-se fazer um acompanhamento do desempenho e funcionalidade da cadeia produtiva desde os insumos necessários à produção até o momento da aquisição do camarão pelo consumidor final. Os resultados indicam que todos os elos descritos necessitam ações que visem desde o melhoramento sanitário e genético das pós-larvas até a comercialização do produto. Desburocratização dos órgãos públicos, maior acesso ao crédito para investimentos, melhorias nas práticas produtivas, capacitação da mão-de-obra técnica e produtiva e redução de custos produtivos não ocorrerão até haver uma normalização das políticas industriais e de comercialização da produção local.

Palavras-chave: Litopenaeus vannamei, carcinicultura, riscos produtivos, cadeia produtiva.

\section{REFERENCES}

ANTONiAlli LM. 1998. Influência da mudança de gestão nas estratégias de uma cooperativa agropecuária. Revista de Administração Contemporânea - RAC, Rio de Janeiro, RJ 4: $135-159$.

BARbieri JÚnior RC AND Ostrensky Neto A. 2002. Camarões marinhos - Engorda. Viçosa: Aprenda Fácil 2: 370 .

BÉNÉ C, CADREN M AND LANTZ F. 2000. Impact of cultured shrimp industry on wild shrimp fisheries: analysis of price determination mechanisms and market dynamics. Agric Econ 23: 55-68.

BRUmmett RE AND Williams MJ. 2000. The evolution of aquaculture in Africa rural and economic development. Ecol Econ 33: 193-203.

Christopher M And TowiLl DR. 2002. Developing Market Specific Supply Chain Strategies. Int J Logist Manag 13: 14.

CORDERO RR, Roth P AND Silva L DA. 2005. Economic growth or environmental protection? The false dilemma of the Latin-American countries. Environ Sci Policy 8: 392-398.

Costa SW, Grumann A, Oliveira Neto FM and Roczanski M. 1998. Cadeias Produtivas do Estado de 
Santa Catarina: Aqüicultura e Pesca. Florianópolis, SC, Epagri, $62 \mathrm{p}$.

Guimarães MC And Brisola MV. 2001. Teoria Motivacional de Maslow e sua Aplicação na Empresa Rural. Revista de Administração e Contabilidade, Unai-MG 01: 37-45.

LAZZARini SG, Machado Filho CP, LAzZARini Neto S AND AIBE H. 1995. Sistema agroindustrial da pecuária de corte: tendências para o próximo século. Revista de Administração Contemporânea, RAC 1(10): 277-292.

NAIM MM, ChILderhouse P, Disney SM AND TOWILl DR. 2002. A Supply chain diagnostic methodology: determining the vector of change. Comput Ind Eng 43: 135-157.

NeIVA CRP. 2002. Valor Agregado e Qualidade do Pescado. Revista Panorama da Aqüicultura, Rio de Janeiro, RJ, p. $46-47$.

Ormond JGP, Mello GAT de, Ferreira PRP AND LIMA CA DE O. 2004. A Carcinicultura Brasileira. BNDES Setorial, Rio de Janeiro, RJ 19: 91-118.

Piedade KR, Neves MF and Santos MJM. 2002. Caracterização da rede produtiva do camarão de água doce no Brasil. Proceedings Anais XI Congresso Brasileiro de Economia e Sociologia Rural, Eqüidade e Eficiência na Agricultura Brasileira Passo Fundo, Rio Grande do Sul: Universidade de Passo Fundo (UPF). Event CD-ROM.
Pio MJ AND MaldonAdo LMO. 2005. Cadeias Produtivas e Competitividade: estudos de prospecção tecnológica. In: Ministério do Desenvolvimento, Indústria E COMÉrCio EXTERIOR; Instituto Euvaldo Lodi (Ed), O Futuro da Indústria: Cadeias Produtivas. $1^{\mathrm{a}}$ ed., Brasília: Athalaia Gráfica e Editora, p. 91-111.

QUINN FJ. 1997. Team up for supply-chain success. Logist Manag 36: 10-39.

RAZzolini EF. 2001. Supply Chain Management - SCM: Uma tentativa de conceituação. Tuiutí, Curitiba, PR, FCSA 24: 79-97.

RIDLER NB AND KABIR M. 1989. The economics of aquaculture. In: BoGHEN AD (Ed), Cold-water aquaculture in Atlantic Canada, Canada, The Canadian Institute on Regional Development, p. 373-395.

VINATEA LAA. 1999. Aqüicultura e desenvolvimento sustentável: subsídios para a formulação de políticas de desenvolvimento da aqüicultura brasileira. $1^{\mathrm{a}}$ ed., Florianópolis: EDUFSC 1: 310. 